\title{
Lactobacillus paralimentarius sp. nov., isolated from sourdough
}

\author{
Yimin Cai, ${ }^{1}$ Hisashi Okada, ${ }^{2}$ Haruhiko Mori, ${ }^{2}$ Yoshimi Benno ${ }^{1}$ \\ and Takashi Nakase'
}

\author{
Author for correspondence: Yimin Cai. Tel: +8148467 9562. Fax: +81484624619. \\ e-mail: cai@ulmus.riken.go.jp
}

\footnotetext{
1 Japan Collection of Microorganisms, The Institute of Physical and Chemical Research, Wako Saitama 351-0198, Japan

2 Laboratory of Microorganism, Takaki Bakery Company Ltd. Hiroshima-shi, Hiroshima 739-0323, Japan
}

\begin{abstract}
Six strains of lactic acid bacteria isolated from sourdough were characterized taxonomically. They were Gram-positive, catalase-negative, facultatively anaerobic rods that did not produce gas from glucose. Morphological and physiological data indicated that the strains belong to the genus Lactobacillus and they were similar to Lactobacillus alimentarius in phenotypic characteristics. These strains shared the same phenotypic characteristics and exhibited intragroup DNA homology values of over $89.8 \%$, indicating that they comprised a single species. The $G+C$ content of the DNA for the strains was 37.2-38.0 mol \%. The 165 rRNA sequence of representative strain TB $1^{\top}$ was determined and aligned with that of other Lactobacillus species. This strain was placed in the genus Lactobacillus on the basis of phylogenetic analysis. $L$. alimentarius was the most closely related species in the phylogenetic tree and this species also showed the highest sequence homology value $(96 \%)$ with strain TB $1^{\top}$. DNA-DNA hybridization indicated that strain TB $1^{\top}$ did not belong to $L$. alimentarius. It is proposed that these strains are placed in the genus Lactobacillus as a new species, Lactobacillus paralimentarius sp. nov. The type strain of $L$. paralimentarius is TB $1^{\mathrm{T}}$, which has been deposited in the Japan Collection of Microorganisms (JCM) as strain JCM 10415'.
\end{abstract}

Keywords: Lactobacillus paralimentarius sp. nov., 16S rRNA, DNA-DNA hybridization

\section{INTRODUCTION}

The genus Lactobacillus encompasses an assemblage of Gram-positive, catalase-negative, non-sporing, rodshaped organisms and is presently composed of over 50 recognized species (Collins et al., 1991). This classification is based on phenotypic and genetic characteristics. The genetic interrelationships of the genus Lactobacillus and related lactic acid bacteria have been studied extensively by using 16S rRNA sequence analysis and DNA-DNA hybridization experiments, and new genera and new species have been added (Cai \& Collins, 1994; Collins et al., 1989, 1993, 1991, 1990). Recent results clearly indicate that the genus Lactobacillus, as presently constituted, is very heterogeneous phylogenetically, and that some Pediococcus and Lactobacillus species exhibit a high degree of $16 \mathrm{~S}$ rRNA sequence similarity with each other and

The DDBJ accession number for the $16 \mathrm{~S}$ rRNA sequence of $T B 1^{\top}$ is $A B 018528$. form a phylogenetically coherent group that is quite separate from other lactic acid bacteria (Collins et al., 1989, 1993, 1991, 1990). Collins et al. (1991) reported that comparative analysis of $16 \mathrm{~S}$ rRNA sequence data revealed the presence of three phylogenetically distinct clusters. Cluster 1 (designated the Lactobacillus delbrueckii group) includes $L$. delbrueckii, the type species of the genus, and 11 other obligately homofermentative species. Cluster 2 (designated the Lactobacillus casei/Pediococcus group) comprises 32 Lactobacillus species (including Lactobacillus alimentarius) and five Pediococcus species. Cluster 3 (designated the Leuconostoc paramesenteroides group) includes the heterofermentative Weissella. The 16S rRNA groups of the genus Lactobacillus do not support the classical division into the subgenera Thermobacterium, Streptobacterium and Betabacterium (Collins et al., 1991) or the three physiological groups (obligately homofermentative, facultatively heterofermentative and obligately heterofermentative) outlined in Bergey's Manual of Systematic Bacteriology (Kandler \& Weiss, 1986). 
Lactobacillus species are widely distributed in various fermented foods, dairy products, and plant and animal material. There have been several reports (Okada et al., 1992; Oura et al., 1982; Spicher, 1984; Spicher \& Schroder, 1978, 1980) of lactobacilli occurring among the dominant microbial population on sourdough, where they may contribute to dough fermentation. Some isolates from sourdough have been identified with an early classification scheme as belonging to the previously described Lactobacillus species (Okada et al., 1992; Spicher, 1984; Spicher \& Schroder, 1978). However, in our experience many isolates cannot be identified as any previously described species.

In the present study, Lactobacillus strains isolated from five samples of sourdough were examined. To determine their taxonomic status, the isolates were also studied by $16 \mathrm{~S}$ rRNA sequence analysis and DNA hybridization experiments, which revealed one new species, for which the name Lactobacillus paralimentarius was proposed.

\section{METHODS}

Strains studied. Six strains were isolated from two samples of sourdough (Takaki Bakery Company) on LBS agar (Becton Dickinson) and Lactobacilli MRS broth (Difco) containing $1.5 \%$ agar incubated at $30^{\circ} \mathrm{C}$ for $2 \mathrm{~d}$ under anaerobic conditions. The sourdough, without yeast or bacteria addition, was fermented at $27^{\circ} \mathrm{C}$ for $12 \mathrm{~h}$. Each strain was purified twice by streaking on MRS agar and the pure cultures were grown in the same agar at $30^{\circ} \mathrm{C}$ for $24 \mathrm{~h}$, suspended with nutrient broth (Difco) and dimethyl sulfoxide in the ratio of $9: 1$ and stored as stock cultures at $-80^{\circ} \mathrm{C}$ for further examination. The Lactobacillus type strains were obtained from the Japan Collection of Microorganisms (JCM), The Institute of Physical and Chemical Research, Wako, Saitama, Japan.

Morphological, physiological and biochemical tests. Gram stain and morphology were examined after $24 \mathrm{~h}$ incubation on MRS agar. Catalase activity, nitrite reduction and gas production from glucose were determined as described by Kozaki et al. (1992). Tests for growth at $\mathrm{pH} 4.5$ and 7.0 , in 4.5 and $7.0 \% \mathrm{NaCl}$, and at $10,15,45$ and $50{ }^{\circ} \mathrm{C}$ were performed in duplicate in MRS broth. Results were recorded after $48 \mathrm{~h}$. Carbohydrate fermentation tests were carried out with the API $50 \mathrm{CH}$ system for Lactobacilli (bioMérieux) according to the manufacturer's instructions; reactions were determined after incubation at $30^{\circ} \mathrm{C}$ for $48 \mathrm{~h}$.

16S rRNA sequencing. The 16S rRNA sequence coding region of strain TB $1^{\mathrm{T}}$ was amplified by PCR performed in a PCR ThermalCycler (Takara Shuzo) as described by Suzuki et al. (1996). The sequences of the PCR products were determined directly by using an ALFexpress AutoCycle Sequence kit (Pharmacia Biotech) with the primers as described by Suzuki et al. (1996). Analyses of DNA sequence reactions were performed with an ALFexpress DNA sequencer (Pharmacia Biotech). The 16S rDNA sequence of strain TB $1^{\mathrm{T}}$ was deposited in the DNA Database of Japan (DDBJ). Nucleotide substitution rates $\left(K_{\text {nue }}\right.$ values) were calculated (Kimura \& Ohta, 1972) and a phylogenetic tree was constructed using the neighbour-joining method (Saitou $\&$ Nei, 1987). The topology of trees was evaluated by bootstrap analysis of the sequence data with CLUSTAL $w$ software (Thompson et al., 1994) based on 100 random resamplings. This sequence was aligned with the following published sequences from DDBJ, GenBank and EMBL: Enterococcus faecalis $\mathrm{JCM} 5803^{\mathrm{T}}$ (AB012212), Enterococcus faecium JCM 5804 ${ }^{\mathrm{T}}$ (AB012213), Lactobacillus acetotolerans DSM 20749 ${ }^{\mathrm{T}}$ (M58801), Lactobacillus acidophilus ATCC $4365^{\mathrm{T}}$ (M58802), Lactobacillus agilis DSM 20509 ${ }^{\mathrm{T}}$ (M58803), L. alimentarius DSM $20249^{\mathrm{T}}(58804)$, Lactobacillus amylophilus DSM 20533 ${ }^{\mathrm{T}}$ (M58806), Lactobacillus amylovorus DSM 20531 ${ }^{\mathrm{T}}$ (M58805), Lactobacillus animalis NCDO $2425^{\mathrm{T}}$ (X61133), Lactobacillus aviarius DSM 20655 ${ }^{\mathrm{T}}$ (M58808), Lactobacillus bifermentans DSM 20003 ${ }^{\mathrm{T}}$ (M58809), Lactobacillus brevis NCDO 1749 (X61134), Lactobacillus buchneri DSM 20057 (M58811), Lactobacillus carnis DSM 20722 ${ }^{\mathrm{T}}$ (M58812), L. casei ATCC 334 ${ }^{\mathrm{T}}$ (D86517), Lactobacillus catenaformis ATCC $25536^{\mathrm{T}}$ (M23729), Lactobacillus collinoides JCM 1123 ${ }^{\mathrm{T}}$ (AB005893), Lactobacillus coryniformis DSM 20001 ${ }^{\mathrm{T}}$ (M58813), L. delbrueckii JCM 1002 (AB007908), Lactobacillus fermentum NCDO $1750^{\top}$ (X61142), Lactobacillus farciminis ATCC 29644 ${ }^{\mathrm{T}}$ (M58817), Lactobacillus fructivorans DSM 20203 ${ }^{\mathrm{T}}$ (X76330), Lactobacillus fructosus NCDO 2345 ${ }^{\mathrm{T}}$ (X61140), Lactobacillus gasseri NCDO 2233 ${ }^{\mathrm{T}}$ (X61137), Lactobacillus helveticus NCDO 2712 ${ }^{\mathrm{T}}$ (X61141), Lactobacillus hilgardii DSM $20176^{\mathrm{T}}$ (M58821), Lactobacillus johnsonii ATCC 33200 ${ }^{\mathrm{T}}$ (AJ002515), Lactobacillus lactis DSM 20072 ${ }^{\mathrm{T}}$ (M58823), Lactobacillus lindneri DSM 20690' (X95421), Lactobacillus mali DSM 20444 ${ }^{\mathrm{T}}$ (M58824), Lactobacillus maltaromicus JCM $1154^{\mathrm{T}}$ (X54420), Lactobacillus minutus (S44204), Lactobacillus murinus DSM 20452 ${ }^{\mathrm{T}}$ (M58826), Lactobacillus oris DSM 4864 ${ }^{\mathrm{T}}$ (X94229), Lactobacillus panis DSM $6035^{\mathrm{T}}$ (X94230), Lactobacillus pentosus JCM 1558 ${ }^{\mathrm{T}}$ (D79211), Lactobacillus plantarum JCM 1149 (D79210), Lactobacillus pontis LTH 2587 (X76329), Lactobacillus rhamnosus JCM $1136^{\mathrm{T}}$ (D16552), Lactobacillus reuteri DSM 20016 ${ }^{\mathrm{T}}$ (L23507), Lactobacillus ruminis DSM 20403 ${ }^{\mathrm{T}}$ (M58828), Lactobacillus sakei DSM 20017 ${ }^{\mathrm{T}}$ (M58829), Lactobacillus salivarius DSM 20554' (M59054), Lactobacillus sanfranciscensis JCM 5668 ${ }^{\mathrm{T}}$ (X61132), Lactobacillus sharpeae DSM 20505 (M58831), Lactobacillus sp. ATCC 8317 (M58832), Lactobacillus vaginalis NCTC $12197^{\mathrm{T}}$ (X61136), Lactobacillus $\mathrm{sp}$. ATCC 13133 (M59295), Lactobacillus zeae ATCC 15820 (D86516), Lactococcus lactis NCDO $2118^{\mathrm{T}}$ (X54260), Pediococcus acidilactici NCDO 2767 ${ }^{\mathrm{T}}$ (X95976), Pediococcus dextrinicus JCM 5887 ${ }^{\mathrm{T}}$ (D87679), Pediococcus parvulus JCM 5889 ${ }^{\mathrm{T}}$ (D88528), Pediococcus pentosaceus DSM 20336 ${ }^{\mathrm{T}}$ (M58834), Weissella confusa NCDO 1586 ${ }^{\mathrm{T}}$ (X52567), Weissella halotolerans DSM $20190^{\mathrm{T}}$ (M23037), Weissella hellenica NCFB $2973^{\mathrm{T}}$ (X95981), Weissella kandleri NCDO $2753^{\mathrm{T}}$ (X52570), Weissella minor NCDO 1973 ${ }^{\mathrm{T}}$ (X52569) and Weissella viridescens NCDO $1655^{\mathrm{T}}$ (X52568). Bacillus subtilis NCDO $1769^{\mathrm{T}}$ (X60646) was used as an outgroup organism.

DNA base composition and DNA-DNA hybridization. DNA was extracted from cells harvested from MRS broth culture which had been incubated for $8 \mathrm{~h}$ at $30^{\circ} \mathrm{C}$. It was purified by the procedure of Saitou \& Miura (1963). DNA base composition was determined by the method of Tamaoka \& Komagata (1984) by using HPLC following enzymic digestion of DNA to deoxyribonucleosides. The equimolar mixture of four deoxyribonucleotides in a GC kit (Yamasa Shoyu) was used as the quantitative standard. DNA-DNA relatedness was determined by the method of Ezaki et al. (1989) by using photobiotin and microplates. 
Table 1. Carbohydrate fermentation patterns of Lactobacillus species

All strains were Gram-positive, catalase-negative rods that produce acid from D-glucose, D-fructose, D-mannose and $N$-acetylglucosamine, but failed to produce acid from erythritol, D-arabinose, L-xylose, adonitol, methyl $\beta$-xyloside, dulcitol, inositol, inulin, xylitol, D-lyxose, D- and L-fucose, D- and L-arabitol, and 2- and 5-ketogluconate. + , Positive; -, negative; + $3 / 5$ strains positive; $w$, weakly positive. Strains: 1 , L. paralimentarius TB $1^{\mathrm{T}} ; 2$, other $L$. paralimentarius isolates $(n=5) ; 3$, L. alimentarius JCM $1095^{\mathrm{T}} ; 4, L$. acidophilus JCM $1132^{\mathrm{T}} ; 5, L$. amylophilus JCM $1125^{\mathrm{T}} ; 6$, L. amylovorus JCM $1127^{\mathrm{T}} ; 7$, L. helveticus JCM $1120^{\mathrm{T}} ; 8$, L. pentosus JCM $1558^{\mathrm{T}} ; 9$, L. plantarum JCM $1149^{\mathrm{T}} ; 10$, L. rhamnosus $\mathrm{JCM}^{1136^{\mathrm{T}}}$.

\begin{tabular}{|c|c|c|c|c|c|c|c|c|c|c|}
\hline Carbohydrate & 1 & 2 & 3 & 4 & 5 & 6 & 7 & 8 & 9 & 10 \\
\hline Glycerol & - & - & - & - & - & - & - & + & - & - \\
\hline L-Arabinose & - & - & - & - & - & - & - & + & + & - \\
\hline Ribose & + & + & + & - & - & - & - & + & + & + \\
\hline D-Xylose & - & - & + & - & - & - & - & + & - & - \\
\hline Galactose & - & - & + & - & + & + & + & + & + & + \\
\hline L-Sorbitol & - & - & - & - & - & - & - & - & - & + \\
\hline Rhamnose & - & - & - & - & - & -- & - & $\mathrm{w}$ & + & + \\
\hline Mannitol & - & - & - & - & - & + & - & + & + & + \\
\hline Sorbitol & - & - & - & - & - & - & - & - & + & + \\
\hline Methyl $\alpha$-D-mannoside & - & - & - & - & - & - & - & - & + & - \\
\hline Methyl $\alpha$-D-glucoside & - & - & - & - & - & - & - & - & + & + \\
\hline Amygdalin & + & + & + & $\mathrm{w}$ & - & + & - & + & + & + \\
\hline Arbutin & + & + & + & - & - & + & - & + & + & + \\
\hline Aesculin & + & + & + & + & - & + & - & + & - & + \\
\hline Salicin & + & + & + & + & - & $\mathrm{w}$ & - & + & + & + \\
\hline Cellobiose & + & + & + & + & - & + & - & + & + & + \\
\hline Maltose & + & +- & + & $\mathrm{w}$ & + & + & + & + & + & + \\
\hline Lactose & - & - & - & + & - & - & + & + & + & + \\
\hline Melibiose & - & - & - & - & - & - & - & + & + & - \\
\hline Saccharose & + & + & + & + & - & + & - & + & + & - \\
\hline Trehalose & + & + & + & + & - & + & + & + & + & + \\
\hline Melezitose & - & - & - & - & - & - & - & - & + & + \\
\hline D-Raffinose & - & - & - & - & - & - & - & - & $\mathrm{w}$ & - \\
\hline Starch & - & - & - & - & + & + & - & - & - & - \\
\hline Glycogen & - & - & - & - & + & + & - & - & - & - \\
\hline$\beta$-Gentiobiose & + & + & - & + & - & + & - & $\mathrm{w}$ & + & + \\
\hline D-Turanose & - & - & - & - & - & - & - & - & + & + \\
\hline D-Tagatose & - & - & - & - & - & - & - & - & - & + \\
\hline Gluconate & - & - & - & - & - & - & - & $\mathrm{w}$ & $\mathrm{w}$ & - \\
\hline
\end{tabular}

\section{RESULTS AND DISCUSSION}

\section{Morphology and biochemical properties}

All isolates were Gram-positive, catalase-negative, facultatively anaerobic rods that did not produce gas from glucose. These isolates were able to grow at $\mathrm{pH}$ 4.5 and in $6.5 \% \mathrm{NaCl}$, but not above $45^{\circ} \mathrm{C}$. As shown in Table 1, strain $\mathrm{TB} 1^{\mathrm{T}}$ and the other five isolates showed the same phenotypic characteristics, with the exception of maltose fermentation patterns. These characteristics were similar to those of L. alimentarius, although $\mathrm{D}$-xylose, galactose and $\beta$-gentiobiose fermentation patterns differed in L. alimentarius and the isolates. These isolates were quite different from other Lactobacillus type strains in some biochemical characteristics and sugar fermentation patterns.
Lactobacillus species are a major component of the microbial flora which are usually present in sourdough sponges (Okada et al., 1992; Spicher, 1984; Spicher \& Schroder, 1978, 1980). Some sourdough-associated lactobacilli have been characterized by phenotypic features and they have been identified as $L$. acidophilus, L. alimentarius, L. brevis, L. buchneri, L. casei, Lactobacillus curvatus, L. farciminis, L. fermentum, L. fructivorans, L. hilgardii, L. reuteri and L. sanfranciscensis (Okada et al., 1992; Oura et al., 1992; Spicher, 1984; Spicher \& Schroder, 1978, 1980). In the present study, all strains were isolated from sourdough and, from their morphology and biochemical properties, these isolates were considered to be typical lactobacilli. As shown in Table 1, the strains were phenotypically similar to L. alimentarius JCM $1095^{\mathrm{T}}$, 


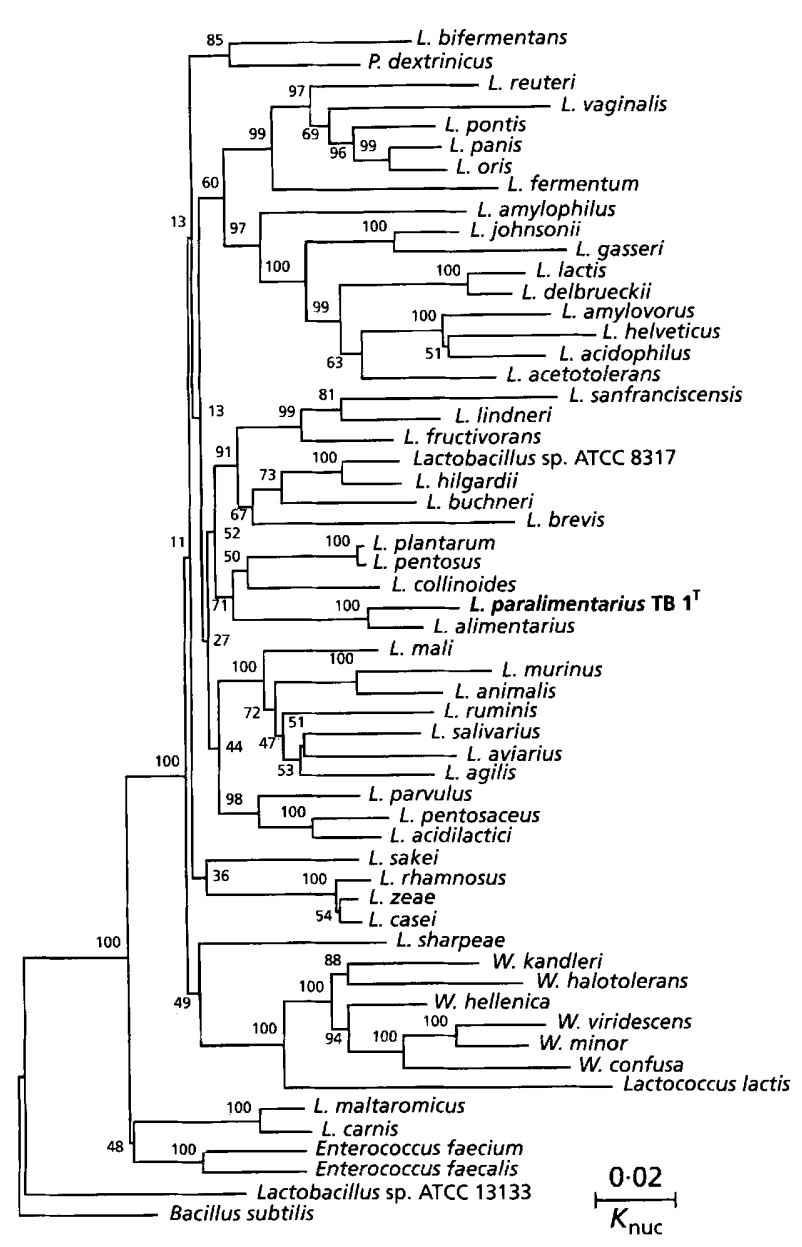

Fig. 1. Phylogenetic tree derived from 165 rDNA sequence of the genus Lactobacillus and related lactic acid bacteria. The tree was created using the neighbour-joining method and $K_{\text {nuc }}$ values. Numbers indicate bootstrap values for branch points. but they differed from $L$. alimentarius $\mathrm{JCM} 1095^{\mathrm{T}}$ in the fermentation patterns of three sugars. These strains can be distinguished from other Lactobacillus species by physiological and biochemical characteristics. Results of the present study have shown that the isolates were closely related to L. alimentarius and that they could not be identified down to a species level on the basis of phenotypic characteristics.

\section{S rRNA sequence and DNA-DNA hybridization}

The 16S rRNA sequence of TB $1^{\mathrm{T}}$ consisted of 1476 bases. The phylogenetic tree shown in Fig. 1 was reconstructed from evolutionary distances by the neighbour-joining method. Phylogenetic analysis placed representative strain $\mathrm{TB} 1^{\mathrm{T}}$ in the cluster comprising L. plantarum JCM $1149^{\mathrm{T}}$, L. pentosus JCM $1558^{\mathrm{T}}$, L. collinoides $\mathrm{JCM} 1123^{\mathrm{T}}$ and $L$. alimentarius JCM $1095^{\mathrm{T}}$. This cluster was recovered in $71 \%$ of the bootstrap trees. L. alimentarius JCM $1095^{\mathrm{T}}$ was the most closely related species in the phylogenetic tree and showed the highest sequence homology value $(96 \%)$ with strain TB $1^{\mathrm{T}}$.

DNA base composition and DNA-DNA hybridization data are shown in Table 2. Strains TB $1^{\mathrm{T}}$, TB 16 , TB 30, TB 56, TB 60 and TB 110 had a $\mathrm{G}+\mathrm{C}$ content of $37.2-38.0 \mathrm{~mol} \%$. The data are within the range for the genus Lactobacillus $(32-53 \mathrm{~mol} \%)$. These strains had DNA homology values of $89 \cdot 8-99 \cdot 7 \%$ with each other, showing that they belonged to a single species, and they had DNA homology values of less than $20.5 \%$ with $L$. alimentarius JCM $1095^{\mathrm{T}}$, and values of less than $12.5 \%$ with $L$. collinoides JCM $1123^{\mathrm{T}}, L$. plantarum JCM $1149^{\mathrm{T}}$ and $L$. pentosus JCM $1558^{\circ}$.

Following 16S rRNA sequence analysis, L. alimentarius formed a relatively long branch indicative of no

Table 2. DNA base compositions and DNA relatedness among Lactobacillus paralimentarius and phylogenetically closely related Lactobacillus species

JCM, Japan Collection of Microorganisms. ${ }^{\mathrm{T}}$, type strain.

\begin{tabular}{|c|c|c|c|c|c|c|}
\hline \multirow[t]{2}{*}{ Strain } & \multirow{2}{*}{$\begin{array}{c}\mathbf{G}+\mathbf{C} \text { content } \\
(\mathrm{mol} \%)\end{array}$} & \multicolumn{5}{|c|}{ DNA-DNA reassociation (\%) with: } \\
\hline & & TB $1^{\mathrm{T}}$ & TB 16 & $\begin{array}{l}\mathrm{JCM} \\
1095^{\mathrm{T}}\end{array}$ & $\begin{array}{l}\mathrm{JCM} \\
1149^{\mathrm{T}}\end{array}$ & $\begin{array}{l}\mathrm{JCM} \\
\mathbf{1 5 5 8}^{\mathrm{T}}\end{array}$ \\
\hline L. paralimentarius $\mathrm{TB} 1^{\mathrm{T}}$ & $37 \cdot 4$ & 100 & $98 \cdot 5$ & $14 \cdot 9$ & $8 \cdot 2$ & $3 \cdot 5$ \\
\hline L. paralimentarius TB 16 & $37 \cdot 8$ & $98 \cdot 4$ & 100 & $18 \cdot 2$ & $3 \cdot 4$ & $4 \cdot 2$ \\
\hline L. paralimentarius TB 30 & $38 \cdot 0$ & $92 \cdot 3$ & $95 \cdot 5$ & $20 \cdot 3$ & $5 \cdot 6$ & $5 \cdot 8$ \\
\hline L. paralimentarius TB 56 & $37 \cdot 2$ & 95.6 & $99 \cdot 7$ & $18 \cdot 7$ & $10 \cdot 3$ & $6 \cdot 4$ \\
\hline L. paralimentarius TB 60 & $37 \cdot 6$ & $98 \cdot 7$ & $93 \cdot 6$ & $15 \cdot 6$ & 8.7 & $7 \cdot 6$ \\
\hline L. paralimentarius TB 110 & $37 \cdot 8$ & $89 \cdot 8$ & $91 \cdot 8$ & $13 \cdot 3$ & $6 \cdot 4$ & $5 \cdot 0$ \\
\hline L. alimentarius $\mathrm{JCM} 1095^{\mathrm{T}}$ & $37 \cdot 5$ & $20 \cdot 5$ & $15 \cdot 6$ & 100 & $3 \cdot 9$ & $4 \cdot 8$ \\
\hline L. collinoides $\mathrm{JCM} 1123^{\mathrm{T}}$ & $45 \cdot 6$ & $7 \cdot 3$ & $12 \cdot 5$ & $7 \cdot 6$ & $15 \cdot 4$ & $13 \cdot 8$ \\
\hline L. plantarum JCM $1149^{\mathrm{T}}$ & $45 \cdot 2$ & $6 \cdot 5$ & $11 \cdot 3$ & $8 \cdot 4$ & 100 & $18 \cdot 7$ \\
\hline L. pentosus JCM $1558^{\mathrm{T}}$ & $44 \cdot 0$ & $8 \cdot 8$ & 8.9 & $6 \cdot 0$ & $18 \cdot 6$ & 100 \\
\hline
\end{tabular}


specific relationship to other species within the $L$. casei/Pediococcus group (Collins et al., 1991). However, in the present study, the tree topology indicated that strain TB $1^{\mathrm{T}}$ formed a cluster only with $L$. alimentarius, and that $L$. plantarum, $L$. pentosus and $L$. collinoides appear only loosely associated with this pair. As shown in Table 2, the DNA-DNA hybridization results demonstrated that strain TB $1^{\mathrm{T}}$ had low levels of DNA relatedness $(<20.5 \%)$ with $L$. alimentarius JCM $1095^{\mathrm{T}}$ and other type strains of previously described species, showing that they were different species.

On the basis of phenotypic and genotypic characteristics, it is concluded that the strains isolated from sourdough represent a new species within the genus Lactobacillus, for which we propose the name Lactobacillus paralimentarius $\mathrm{sp}$. nov.

\section{Description of Lactobacillus paralimentarius sp. nov.}

Lactobacillus paralimentarius (pa.ra.li.men.ta'ri.us. Gr. pref. para beside; L. adj. alimentarius pertaining to food).

Grows well anaerobically on MRS agar at $37^{\circ} \mathrm{C}$ and cells are facultatively anaerobic and heterofermentative, Gram-positive, catalase-negative, non-sporing, non-motile rods with a length of about $4 \cdot 0-7 \cdot 0 \mu \mathrm{m}$ and a width of $0.7-1 \cdot 0 \mu \mathrm{m}$. Growth occurs at $\mathrm{pH} 4.5,40^{\circ} \mathrm{C}$ and $6.5 \% \mathrm{NaCl}$, but not above $45^{\circ} \mathrm{C}$. Acid is produced from ribose, D-glucose, D-fructose, D-mannose, $N$ acetylglucosamine, amygdalin, arbutin, aesculin, salicin, cellobiose, saccharose, trehalose and $\beta$-gentiobiose. Acid is not produced from glycerol, erythritol, D- and L-arabinose, D- and L-xylose, adonitol, methyl $\beta$-xyloside, galactose, L-sorbitol, rhamnose, dulcitol, inositol, mannitol, sorbitol, methyl $\alpha$-D-mannoside, methyl $\alpha$-D-glucoside, lactose, melibiose, inulin, melezitose, D-raffinose, starch, glycogen, xylitol, D-turanose, D-lyxose, D-tagatose, D- and L-fucose, D- and Larabitol, gluconate or 2- and 5-ketogluconate. Three of the six strains were positive for maltose. DNA $\mathrm{G}+\mathrm{C}$ content is $37 \cdot 2-38.0 \mathrm{~mol} \%$, as determined by HPLC. Type strain is TB $1^{\mathrm{T}}\left(=\mathrm{JCM} 10415^{\mathrm{T}}\right)$.

\section{REFERENCES}

Cai, J. \& Collins, M D. (1994). Evidence for a close phylogenetic relationship between Melissococcus pluton, the causative agent of European foulbrood disease, and the genus Enterococcus. Int $J$ Syst Bacteriol 44, 365-367.

Collins, M. D., Ash, C., Farrow, J. A., Wallbanks, S. \& Williams, A. M. (1989). 16S ribosomal ribonucleic acid sequence analyses of lactobacilli and related taxa. Description of Vagococcus fluvialis gen. nov., sp. nov. J Appl Bacteriol 67, 453-460.

Collins, M. D., Williams, A. M. \& Wallbanks, S. (1990). The phylogeny of Aerococcus and Pediococcus as determined by $16 \mathrm{~S}$ rRNA sequence analysis: description of Tetragenococcus gen. nov. FEMS Microbiol Lett 70, 255-262.

Collins, M. D., Rodrigues, U., Ash, C., Aguirre, M., Farrow, J. A. E., Martinez-Murcia, A., Phillips, B. A., Williams, A. M. \& Wallbanks, S. (1991). Phylogenetic analysis of the genus Lactobacillus and related lactic acid bacteria as determined by reverse transcriptase sequencing of $16 \mathrm{~S}$ rRNA. FEMS Microbiol Lett 77, $5-12$.

Collins, M. D., Metaxopoulos, J. \& Wallbanks, S. (1993). Taxonomic study on some leuconostoc-like organisms from fermented sausages: description of a new genus Weissella for the Leuconostoc paramesenteroides group of species. $J$ Appl Bacteriol 75, 595-603.

Ezaki, T., Hashimoto, Y. \& Yabuuchi, E. (1989). Fluorometric deoxyribonucleic acid-deoxyribonucleic acid hybridization in microdilution wells as an alternative to membrane filter hybridization in which radioisotopes are used to determine genetic relatedness among bacterial strains. Int J Syst Bacteriol 39, 224-229.

Kandler, O. \& Weiss, N. (1986). Genus Lactobacillus. In Bergey's Manual of Systematic Bacteriology, vol. 2, pp. 1209-1234. Edited by P. H. A. Sneath, N. S. Mair, M. E. Sharpe \& J. G. Holt. Baltimore: Williams \& Wilkins.

Kimura, M. \& Ohta, T. (1972). On the stochastic model for estimation of mutation distance between homologous proteins. $J$ Mol Evol 2, 87-90.

Kozaki, M., Uchimura, T. \& Okada, S. (1992). Experimental Manual for Lactic Acid Bacteria, pp. 29-72. Tokyo: Asakurasyouten.

Okada, S., Ishikawa, M., Yoshida, I., Uchimura, T., Ohara, N. \& Kozaki, M. (1992). Identification and characteristics of lactic acid bacteria isolated from sourdough sponges. Biosci Biotechnol Biochem 56, 572-575.

Oura, H., Suomalainen, H. \& Viskari, R. (1982). Breadmaking. In Economic Microbiology, vol. 7, Fermented Food, pp. 88-146. Edited by A. H. Rose. London: Academic Press.

Saitou, H. \& Miura, K. (1963). Preparation of transforming deoxyribonucleic acid by phenol treatment. Biochim Biophys Acta 72, 619-629.

Saitou, N. \& Nei, M. (1987). The neighbor-joining method: a new method for reconstructing phylogenetic trees. Mol Biol Evol 4, 406-425.

Spicher, G. (1984). The microflora of sourdough. XVII. Communication: bacterial composition of commercial sourdough starters. Z Lebensm Unters Forsch 178, 106-109.

Spicher, G. \& Schroder, R. (1978). The microflora of sourdough. IV. Communication: bacterial composition of sourdough starters (Genus Lactobacillus Beijerinck). Z Lebensm Unters Forsch 167, 342-354.

Spicher, G. \& Schroder, R. (1980). The microflora of sourdough. IX. Communication: comparative investigations over the performance of lactic acid bacteria (Genus Lactobacillus Beijerinck) occurring in starter cultures ('Reinzuchtsauer'). $Z$ Lebensm Unters Forsch 170, 262-266.

Suzuki, K., Sasaki, J., Uramoto, M., Nakase, T. \& Komagata, K. (1996). Agromyces mediolanus sp. nov., nom. rev., comb. nov., a species for 'Corynebacterium mediolanum' Mamoli 1939 and for some aniline-assimilating bacteria which contain 2,4diaminobutyric acid in the cell wall peptidoglycan. Int $J$ Syst Bacteriol 46, 88-93.

Tamaoka, J. \& Komagata, K. (1984). Determination of DNA base composition by reversed-phase high-performance liquid chromatography. FEMS Microbiol Lett 25, 125-128.

Thompson, J. D., Higgins, D. G. \& Gibson, T. J. (1994). CLUSTAL $\mathrm{W}$ : improving the sensitivity of progressive multiple sequence alignment through sequence weighting, position-specific gap penalties and weight matrix choice. Nucleic Acids Res 22, 4673-4680. 